\title{
Counselling for prenatal diagnosis of sickle cell disease and $\beta$ thalassaemia major: a four year experience
}

\author{
E N ANIONWU*, N PATEL*, G KANJI $\dagger$, H RENGES \\ AND M BROZOVIĆ $\S$ \\ From *the Brent Sickle Cell and Thalassaemia Centre, Willesden Hospital, London; the Antenatal Clinic and \\ $\S$ Department of Haematology, Central Middlesex Hospital, London; and $\ddagger$ the Medical Faculty, Bonn \\ University, FRG.
}

SUMMARY A non-directive programme of prenatal counselling was used during a four year period. Forty-three couples at risk for having a baby with a haemoglobinopathy were identified. Prenatal diagnosis was offered in 19 pregnancies to 14 couples at risk of having a baby with sickle cell anaemia and in two pregnancies in two couples at risk of a baby with $\beta$ thalassaemia major, who presented before the 18th week of pregnancy. Six couples at risk for sickle cell anaemia accepted prenatal diagnosis in 10 pregnancies, as did both couples at risk for thalassaemia. Couples who were eligible for prenatal diagnosis but refused it tended not to have been informed about sickle cell disease before counselling, one partner was more frequently absent at the time of the initial counselling session, or they either had no children with sickle cell disease or the children were not severely affected. Other factors influencing their decision included a poor obstetric history and rejection of abortion, mainly on moral grounds.

The approximately $50 \%$ uptake of prenatal diagnosis in this initial study highlights the complex issues involved. Our experience indicates that with systematic screening and counselling in the antenatal clinic, and with increased awareness of the haemoglobinopathies, couples at risk will be in a better position to make informed decisions.

Prenatal diagnosis of the haemoglobinopathies has developed rapidly ${ }^{1-4}$ and is now widely available in Britain for couples at risk for $\beta$ thalassaemia major and sickle cell disease. Sickle cell disease is a major health problem for the Afro-Caribbean peoples living in Britain, ${ }^{5}$ as is $\beta$ thalassaemia major for those originating from the Mediterranean area and the Indian subcontinent. ${ }^{6}$ In 1979 , Brent Sickle Cell and Thalassaemia Centre was established with the aim of informing the patients, their parents, and the communities at risk about these conditions and their genetic implications. ${ }^{7}$ Starting from March 1982, all non-European women attending the antenatal clinic at Central Middlesex Hospital have been screened for abnormal haemoglobins, and since January 1985 all women, regardless of their ethnic origin, have been screened for both a variant haemoglobin and for $\beta$ thalassaemia trait. Since 1982 , the counsellors of the Brent Sickle Cell and Thalassaemia Centre have counselled all heterozygous women identified by prenatal screening.

This paper reports the outcome of counselling and uptake of prenatal diagnosis.

\section{Subjects and methods}

A total of 4500 women attending the antenatal clinic has been screened in the four year period from March 1982 to February 1986 inclusive (2302 screened for an abnormal haemoglobin only, and 2198 screened for both an abnormal haemoglobin and $\beta$ thalassaemia trait). A total of 335 was found to be heterozygous for an abnormal haemoglobin or $\beta$ thalassaemia trait. The detailed breakdown of these results will be reported separately. ${ }^{8}$ Seventyone percent of partners attended for a blood test and 35 couples ( 40 pregnancies) at risk of producing a baby with a clinically significant haemoglobinopathy were detected. Eight additional couples identified elsewhere attended the Brent Sickle Cell and 
Thalassaemia Centre for counselling, giving a total of 43 couples at risk seen in 49 pregnancies. The haemoglobin genotypes of couples at risk and their ethnic origin are shown in table 1.

Heterozygous women were counselled at the antenatal clinic by one of the counsellors and invited to ask their partner to attend for a blood test. Couples where both partners had an abnormal haemoglobin or $\beta$ thalassaemia trait or both were invited for a second counselling session. All were given the Sickle Cell Society handbook on sickle cell disease or the UK Thalassaemia Society leaflet on thalassaemia trait. The nature of their respective traits, the genetic implications of recessive inheritance, the characteristics of the homozygous condition in the child, and the availability of help were explained and discussed. In the case of sickle cell disease, the clinical variability of the disease was emphasised. The interview was non-paternalistic and as much factual information as possible was offered, to enable the couple to make an informed decision. The methods and risks of prenatal diagnosis and the possible termination of pregnancy were discussed in detail with couples at risk of having a baby with sickle cell anaemia (SS) or $\beta$ thalassaemia major presenting before the 18th week of pregnancy. These couples were offered additional counselling sessions, as well as an opportunity of talking with doctors, staff at prenatal diagnostic centres, and, through the voluntary organisations, families with affected children and couples who had had prenatal diagnosis. Thirteen of the 17 couples requested additional sessions.

Couples at risk for SC disease and $S / \beta$ thalassaemia were informed about the milder nature of these conditions. While prenatal diagnosis was mentioned, it was discussed in detail only if the couple requested more information. The cord blood screening policy for babies born at the hospital was described to all couples at risk.

\section{Results}

AS $\times$ AS COUPLES

A total of 22 couples was at risk of having a child

TABLE 1 Ethnic origin of couples at risk.

\begin{tabular}{|c|c|c|c|c|c|c|}
\hline \multirow{2}{*}{ Hb type } & \multicolumn{6}{|c|}{ Ethnic origin } \\
\hline & $W$ Indies & $W$ Africa & Malawi & India/Pakistan & Other* & Total \\
\hline AS/AS & 5 & 15 & 1 & 0 & 1 & 22 \\
\hline AS/AC & 9 & 6 & 0 & 0 & 0 & 15 \\
\hline$\beta$ thal $/ \beta$ thal & 0 & 0 & 0 & 3 & 0 & 3 \\
\hline Others $\dagger$ & 2 & 1 & 0 & 0 & 0 & 3 \\
\hline Total & 16 & 22 & 1 & 3 & 1 & 43 \\
\hline
\end{tabular}

$*=\mathrm{W}$ Indies/W Africa.

$\dagger=\mathrm{SS} / \mathrm{AC}, \mathrm{SC} / \beta$ thal trait, and $\mathrm{AS} / \beta$ thal trait. with sickle cell anaemia ( $\mathrm{Hb} \mathrm{SS}$ ) in 28 pregnancies. $\stackrel{\overparen{D}}{?}$ Only eight couples were already aware of being at $\overrightarrow{\vec{F}}$ risk and seven of these had children with sickle cell $\stackrel{?}{\rightarrow}$ disease. Fourteen couples had no previous knowledge of being at risk, although this was the first $\frac{\bar{c}}{\bar{D}}$ pregnancy for only seven of them.

Fifteen couples were identified sufficiently early $\stackrel{\mathbb{\Omega}}{\Omega}$ to be eligible for prenatal diagnosis. One was soon lost to follow up. Six accepted prenatal diagnosis in $\vec{\circ}$ 10 pregnancies (two in two pregnancies and one in three pregnancies). Five of these six couples already $\vec{\omega}$ had children with sickle cell disease. In the only couple who did not have any children with sickle cell disease, the fetus was found to be homozygous for $\mathrm{Hb} S$ and the couple decided to terminate the pregnancy.

The outcome of the 20 pregnancies of the 14 \%े couples remaining is shown in table 2 . Seven couples 6 refused prenatal diagnosis and one couple was 은 advised against the test because of a poor obstetric history. These couples are compared with those who $z$ accepted prenatal diagnosis in table 3. Among those $\underset{\mathbb{D}}{\overparen{ }}$ who refused, partners were more often absent at the 3 time of the initial counselling and more couples had not been aware of the risk before counselling. $\vec{P}$ Parents whose children were severely affected (f $\&$ example, because of a stroke) were the ones mok likely to accept prenatal diagnosis. Two couples refused prenatal diagnosis on religious grounds (one in two pregnancies) and five were opposed to termination on principle.

TABLE $2 A S \times A S$ couples offered prenatal diagnosis: outcome of pregnancy.

\begin{tabular}{lllllll}
\hline $\begin{array}{l}\text { Accepted } \\
P N D\end{array}$ & $\begin{array}{l}\text { No of } \\
\text { couples }\end{array}$ & $\begin{array}{l}\text { No of } \\
\text { pregnancies }\end{array}$ & AA & AS & \multicolumn{2}{l}{\begin{tabular}{l} 
Outcome \\
\cline { 3 - 6 }
\end{tabular}} \\
\hline Yes & 6 & 10 & 2 & 5 & $1^{*}$ & $2 \dagger$ \\
No & 8 & 9 & 0 & 5 & 3 & 1 \\
Total & 14 & 19 & 2 & 10 & 4 & 3 \\
\hline
\end{tabular}

*Terminated.

†Both occurred before date of proposed prenatal diagnosis.

TABLE 3 A comparison of eligible couples who accepted prenatal diagnosis with those who refused.

\begin{tabular}{llll}
\hline Couples at risk of SS & \multicolumn{3}{l}{ Prenatal diagnosis } \\
\cline { 2 - 4 } & $\begin{array}{l}\text { Total } \\
(n=13)\end{array}$ & $\begin{array}{l}\text { Accepted } \\
(n=6)\end{array}$ & $\begin{array}{l}\text { Refused } \\
(n=7)\end{array}$ \\
\hline $\begin{array}{l}\text { Previous knowledge of SS } \\
\text { Partner present at the }\end{array}$ & 9 & 6 & 3 \\
$\quad$ initial interview & 10 & 6 & 4 \\
Child with SS & 7 & 5 & 2 \\
Child with SS and CVA* & 4 & 4 & 0 \\
Child died from SS & 1 & 1 & 0 \\
\hline *CVA =cerebrovascular accident. & &
\end{tabular}

*CVA = cerebrovascular accident. 
TABLE 4 Outcome of pregnancies in the couples who were not offered prenatal diagnosis.

\begin{tabular}{|c|c|c|c|c|c|c|c|}
\hline \multirow{2}{*}{$\begin{array}{l}\text { Genotype of } \\
\text { parents }\end{array}$} & \multirow{2}{*}{$\begin{array}{l}\text { No of } \\
\text { couples }\end{array}$} & \multicolumn{6}{|c|}{ Outcome of pregnancy } \\
\hline & & $A A$ & $A S$ & $A C$ & $S S$ & $S C$ & Other \\
\hline AS $\times$ AS & 8 & 1 & 4 & - & 3 & - & - \\
\hline $\mathrm{AS} \times \mathbf{A C}$ & 15 & 3 & 2 & 3 & - & 6 & SB* $^{*}$ \\
\hline $\mathbf{S S} \times \mathbf{A C}$ & 1 & - & - & - & - & - & $1 \dagger$ \\
\hline$S C \times \beta$ thal trait & 1 & - & - & - & - & - & $C-\beta$ thal \\
\hline$A S \times \beta$ thal trait & 1 & - & 1 & - & - & - & - \\
\hline Total & 26 & 4 & 7 & 3 & 3 & 6 & 3 \\
\hline
\end{tabular}

*Stillbirth.

†Moved; lost to follow up.

Eight couples were either identified or presented too late for prenatal diagnosis to be discussed, and three of these produced a baby with homozygous sickle cell disease (table 4). In this group only one couple was already aware of the risk, as they had three children with sickle cell anaemia. (They had recently arrived from Nigeria and the pregnancy was too advanced for prenatal diagnosis to be discussed.) Four additional couples (two of whom had children with SS) stated that they would wish to have prenatal diagnosis in the next pregnancy, and one actually had a prenatal diagnosis in the subsequent pregnancy.

\section{COUPLES AT RISK FOR HB SC DISEASE AND} OTHER HAEMOGLOBINOPATHIES

In the same period we saw 16 couples at risk for having a baby with $\mathrm{Hb}$ SC disease, one at risk for haemoglobin $S / \beta$ thalassaemia, and one where the mother had $\mathrm{Hb}$ SC disease and the father thalassaemia trait. None of these couples was offered prenatal diagnosis, although it was discussed and a detailed explanation of the haemoglobinopathy was given. Only four of the couples were previously aware of being at risk, two because they already had children with $\mathrm{Hb} \mathrm{SC}$ disease. Among those unaware of risk were five multiparas: all their families were studied and two previously undiagnosed children with $\mathrm{Hb}$ SC disease were found. The outcome of pregnancies for this group is shown in table 4. Six babies had $\mathrm{Hb} \mathrm{SC}$ disease, one of these being born to the couple who already had four other children with $\mathrm{Hb} \mathrm{SC}$ disease.

COUPLES AT RISK FOR THALASSAEMIA MAJOR We have counselled three couples at risk for $\beta$ thalassaemia major; one Sikh couple, one Hindu Indian couple, and one Muslim Pakistani couple whose risk was identified only when they transferred to the hospital at 28 weeks of pregnancy, so prenatal diagnosis could not be offered. The other two couples (neither of whom was previously aware of risk) accepted prenatal diagnosis; one had amniocentesis and the other (a twin pregnancy) had fetoscopy and all three babies were shown not to have thalassaemia major. The diagnoses were confirmed after birth.

\section{Discussion}

When prenatal diagnosis is offered to a minority population, ${ }^{9}$ cultural, linguistic, religious, social, and economic factors must be taken into account. This is particularly important for sickle cell anaemia since the clinical variability of the disease complicates the issue of prenatal diagnosis with ethical and moral dilemmas. The clinical course is severe in about one-third of those affected, with at least a 7\% incidence of stroke in children, ${ }^{10}$ and the parents must be given detailed information and the choice of prenatal diagnosis.

The limited experience reported here shows that counselling helps to identify a group of parents-tobe who hold strong and clear views on the necessity of prenatal diagnosis. It is of interest that four of the five couples with such clearly defined views have had children with sickle cell disease and cerebrovascular accidents. No pressure should be exerted on couples who are uncertain or find it difficult to make up their minds, whether because of lack of previous information and experience with the condition, or religious or moral principles. Talking to parents of patients with sickle cell disease or thalassaemia major, or to the patients themselves, often helps couples to decide whether or not to proceed with prenatal diagnosis. In view of the $50 \%$ uptake among couples who were counselled in time, it is not surprising that four of the nine couples who were not eligible for prenatal diagnosis by dates stated that they will accept prenatal diagnosis in the next pregnancy, and one has already done so. Our very small experience with Asian couples showed that both couples eligible were able to accept prenatal diagnosis. We have not offered prenatal diagnosis to couples at risk for other sickle haemoglobinopathies but think the topic is open to discussion.

We thank the staff of the Haematology Department, Central Middlesex Hospital for carrying out the tests, the staff of the Antenatal Clinic at the Central Middlesex Hospital for their cooperation and help, and the Sickle Cell and UK Thalassaemia Societies for arranging for the couples to meet other children and parents willing to discuss their problems.

\footnotetext{
References

${ }^{1}$ WHO Working Group. Hereditary anaemias: genetic basis,
} 
clinical features, diagnosis and treatment. Bull WHO 1982;60: 643-60.

2 Memorandum from a WHO meeting. Community control of hereditary anaemias. Bull WHO 1983;61:63-80.

${ }^{3}$ Progress in the community control of thalassaemia. Report of the second annual meeting of the WHO Working Group for the community control of hereditary anaemias, Nicosia, Cyprus, 29 to 31 November, 1982. Unpublished WHO document 1983 , HMG/WG/83.9.

4 Weatherall DJ, Old JM, Thein SL, Wainscoat JS, Clegg JB. Prenatal diagnosis of the common haemoglobin disorders. $J$ Med Genet 1985;22:422-30.

5 Brozovic M, Anionwu E. Sickle cell disease in Britain. J Clin Pathol 1984;37:1321-6.

6 Modell B, Berdoukas V. The clinical approach to thalassaemia. New York: Grune \& Stratton, 1984.

${ }^{7}$ Prashar U, Anionwu E, Brozovic M. In: Sickle cell anaemia- who cares? Chap 3. Sickle Cell Centres, 31-38, Runnymede Trust, 1985.

${ }^{8}$ Henthorn J, Anionwu E, Brown M, Kanji G, Brozovic M Davis SC. Screening for haemoglobinopathies in the antenatal clinic. To be published.

${ }^{9}$ Murray RF, Chamberlain N, Fletcher J, et al. Special considerations for minority participation in prenatal diagnosis. JAMA 1980;243:1254-6.

10 Serjeant GR. Sickle cell disease. Oxford: Oxford University ڤ Press, 1985.

Correspondence and requests for reprints to Ms Elizabeth N Anionwu, Brent Sickle Cell and Thalassaemia Centre, Willesden Hospital, Harlesden $\widehat{\varrho}$ Road, London NW10 3RY. 